\title{
PENGARUH PEMBERIAAN DEKOKTA LUKA BAHAU (Cinnamomum verum) TERHADAP PERUBAHAN KADAR MALONDIALDEHIDA (MDA) PADA TIKUS PUTIH (Rattus norvegicus) YANG DIPAPARKAN ASAP ROKOK
}

\author{
Kiki Argananta*, Lizma Febrina, Laode Rijai \\ Laboratorium Penelitian dan Pengembangan FARMAKA TROPIS \\ Fakultas Farmasi Universitas Mulawarman, Samarinda, Kalimantan Timur \\ *email : arganantakiky@gmail.com
}

\begin{abstract}
ABSTRAK
Kulit batang Luka Bahau (Cinnamomum verum) secara in vitro menunjukan adanya aktivitas antioksidan yang tinggi dan telah diketahui memiliki nilai $\mathrm{IC}_{50} 0.62 \mu \mathrm{g} / \mathrm{mL}$. Penelitian ini bertujuan untuk mengetahui apakah pemberian dekokta Luka Bahau selama 7 hari mampu memberi pengaruh terhadap peroksidasi lipid berdasarkan pengukuran kadar malondialdehida (MDA) pada hewan coba yang dipaparkan asap rokok sebanyak 1 batang setiap pagi, siang dan sore. Proses penelitian meliputi pengumpulan kulit batang Luka Bahau, pembuatan dekokta, dan pengujian pengaruh dekokta Luka Bahau. Sebanyak dua puluh lima tikus jantan galur wistar dengan berat \pm 200 gram dibagi ke dalam lima kelompok perlakuan yaitu kontrol normal, kontrol negatif, dan tiga kelompok yang diberi paparan asap rokok dan dekoktaCinnamomum verum dengan konsentrasi $2,3 \% ; 3,13 \% ; 4,1 \% / \mathrm{kg}$ BB. Kadar MDA dianalisis menggunakan metode TBARS (Thiobarbituric Acid Reactive Substance) yang diukur dengan spektrofotometer UV-Vis pada $\chi=531 \mathrm{~nm}$. Pemberian dekokta Cinnamomum verum pada konsentrasi $3,13 \%$ dan $4,1 \%$ dapat menekan terjadinya peroksidasi lipid yang ditunjukkan dengan penurunan kadar MDA secara berturut-turut sebesar 17,4\% dan $38 \%$ pada tikus yang terpapar asap rokok dibandingkan dengan kelompok dekokta 2,3\% dan kontrol negatif.
\end{abstract}

Kata kunci: Cinnamomum verum, asap rokok, Malondialdehida, antioksidan.

\begin{abstract}
Luka Bahau (Cinnamomum verum) bark showed a high activity inin vitro study and are known have IC $C_{50}$ value of $0.62 \mathrm{mg} / \mathrm{mL}$. A research was conducted to observe its effects dekokta Luka Bahau for 7 days on lipid peroxidation as shown by malondialdehyde (MDA) level in cigarette smoke exposed rats. Rats were exposed to cigarette smoke three times per day using 1 cigarette per rat. This research's process consists of collection of the stem barks, extraction of the stemBark with dekokta methods and and testing of the effect of dekokta.Twenty five male wistar rats were divided into five groups, i.e. : control normal, negative control and three groups received cigarette smoke exposure and Cinnamomum verum steam bark dekokta with a concentration of 2,3\%; 3,13\%; 4,1\% $/ \mathrm{kg} \mathrm{BW}$. The MDA levels was analyzed with Thiobarbituric Acid Reactive Substance (TBARS) method by spectrophotometer $U V$-Vis in $\chi=531 \mathrm{~nm}$. The use of Cinnamomum verum steam bark dekokta at 3,13\% and 4,1\% concentration was able to prevent the occurrence of lipid peroxidation as shown by the MDA levels $17.4 \%$ and $38 \%$, respectively and the effect was compared with dekokta 2,3\% and a negative control.
\end{abstract}

Keywords: Cinnamomum verum, Malondialdehyde, cigarette smoke, antioxidant. 


\section{PENDAHULUAN}

Indonesia merupakan negara ketiga yang memiliki jumlah perokok aktif terbanyak di dunia yaitu 61,4 juta perokok setelah Cina dan India. Perilaku merokok penduduk Indonesia cenderung meningkat dari 34,2\% pada tahun 2007 menjadi 36,3\% pada tahun $2013^{1}$. Asap rokok terdiri atas campuran substansi-substansi kimia dalam bentuk gas dan partikel-partikel terdispersi di dalamnya. Sampai saat ini, telah berhasil diisolasi beragam zat kimia yang jumlahnya mencapai 4000 senyawa dalam asap rokok. Sebagian besar bahan atau senyawa tersebut bersifat toksik dalam bentuk gas, yaitu berupa karbon monoksida (CO), hidrogen sianida ( $\mathrm{HCN})$, dan oksida nitrogen (NO), sedangkan substansi toksik dalam bentuk zat kimia volatile yaitu nitrosamine dan formaldehida ${ }^{2}$. Oksidan dalam rokok terutama oksida nitrogen (NO) akan menurunkan jumlah antioksidan intraseluler dan memainkan peran yang besar dalam penghasilan radikal $\mathrm{O}^{*}, \mathrm{H}_{2} \mathrm{O}_{2}$ dan $\mathrm{HO}^{*}$. Dilihat dari zat yang dikandungnya, merokok dapat meningkatkan level radikal bebas di dalam tubuh ${ }^{3}$. Radikal bebas bersifat dekstruktif, sangat reaktif dan mampu bereaksi dengan makromolekul dalam tubuh, salah satunya dengan lipid (fosfolipid) pada membran sel. Lipid merupakan salah satu molekul yang paling sensitif terhadap serangan radikal bebas sehingga terbentuk lipid peroksida yang selanjutnya akan dihasilkan malondialdehida. Senyawa ini dijadikan biomarker kadar radikal bebas di dalam tubuh ${ }^{4}$. Konsentrasi MDA yang tinggi menunjukkan jumlah radikal bebas yang tinggi pula di dalam tubuh. Meningkatnya kadar MDA di dalam tubuh menggambarkan kerusakan sel, dalam hal ini diawali oleh rusaknya membran sel, sehingga akan mengakibatkan terganggunya proses metabolisme di dalam tubuh ${ }^{5}$.

Peroksidasi lipid dari hasil radikal bebas dapat di cegah dengan menggunakan antioksidan. Sumber antioksidan alami salah satunya adalah kayu manis. Senyawa kayu manis yang berperan sebagai antioksidan adalah senyawa polifenol. Mekanisme kerja polifenol sebagai penangkal (scavenger) radikal bebas ${ }^{6}$. Tumbuhan kayu manis sering digunakan secara tradisonal untuk penyembuhan luka, penambah cita rasa dan minuman kesehatan ${ }^{6}$. Kayu manis dapat dijadikan sebagai antioksidan potensial karena mengandung senyawa kimia berupa fenol, terpenoid dan saponin. Ekstrak antioksidan kulit batang luka Bahau (Cinnamomumverum) secara in vitro menunjukan adanya aktivitas antioksidan yang tinggi, dibuktikan dengan membandingkan nilai inhibition concentration $\left(\mathrm{IC}_{50}\right)$ pada

beberapa tanaman. Pada penelitian identifikasi metabolit sekunder dan aktivitas antioksidan ekstrak kulit batang luka Bahau (Cinnamomum verum) menerangkan nilai $\mathrm{IC}_{50}$ pada antioksidan kulit kayu luka Bahau (Cinnamomum verum) $0.62 \mu \mathrm{g} / \mathrm{mL}$. Berdasarkan uraian diatas, maka perlu diteliti pengaruh dekokta kulit kayu luka Bahau (Cinnamomum verum) terhadap kadar malondialdehida pada tikus putih yang diberi paparan asap rokok.

\section{METODE PENELITIAN}

\section{Alat}

Box induksi kaca, gunting bedah, holder, mikropipet, hot plate, sentrifuge,spektrofotometri UV-Vis, timbangan analitik, timbangan hewan, glukometer, microtube.

\section{Bahan}

Air suling, asam tiobarbiturat (TBA), asam trikloro asetat (TCA), etanol 70\%, kapas,dan tetra metoksi propana (TMP), rokok filter. 


\section{Prosedur}

\section{Persiapan Hewan Coba}

Disiapkan hewan coba, yakni tikus putih sehat dengan anggota tubuh yang lengkap dan normal. Kemudian dikelompokkan menjadi 2 kelompok yang berbeda, yakni kelompok kontrol dan kelompok eksperimen, masing-masing kelompok berjumlah 5 ekor. Diberikan pakan standar, berupa pellet dan minuman standar, berupa air minum secara rutin dan teratur serta diperhatikan kebersihan kandang serta penggantian sekam setiap 2 hari sekali. Hewan coba tidak diberikan perlakuan uji pada minggu pertama sebagai waktu untuk beradaptasi di lingkungan yang baru.

\section{Persiapan Bahan Uji}

Disiapkan bahan uji, berupa asap dari rokok jenis rokok filter.

\section{Pemaparan Asap Rokok}

Dimasukkan hewan coba dalam chamber induksi yang berukuran 38,5 × 28,5 × 22,5 $\mathrm{cm}$ lengkap dengan ventilasi udara, dialirkan asap yang telah dikumpulkan dalam chamber pengumpul asap hingga asap habis. Proses pemaparan dilakukan setiap pagi, siang dan sore hari dengan menggunakan asap dari 1 batang rokok selama tujuh hari.

\section{Pembuatan Kurva Baku Tetra Metoksi Propan (TMP)}

Dibuat larutan TMP dengan konsentrasi $20 \mathrm{nmol} / \mathrm{mL}$ sebagai standar dalam pengujian kadar MDA sampel. Diambil dari larutan stok tersebut sebanyak 0,$3 ; 0,65 ; 1,25$; 2,5; 5 dan $10 \mathrm{nmol} / \mathrm{mL}$. Lalu dimasukkan $1 \mathrm{~mL}$ ke dalam 5 buah labu ukur yang berbeda. Ditambahkan Asam Trikloroasetat (TCA) 20\% sebanyak $1 \mathrm{~mL}$ ke dalam setiap labu ukur, lalu dikocok hingga homogen. Ditambahkan Aquadest ke dalam setiap labu ukur hingga volumenya mencapai $10 \mathrm{~mL}$. Ditambahkan reagen Asam Tiobarbiturat (TBA) 0,01\% sebanyak $1 \mathrm{~mL}$ ke dalam setiap labu ukur, dikocok kembali hingga homogen. Digunakan larutan yang sama tanpa TMP sebagai blanko. Dimasukkan semua tabung reaksi ke dalam pemanas air pada suhu $100^{\circ} \mathrm{C}$ selama 10 menit, lalu didinginkan. Diukur absorbansi pada $\chi=531 \mathrm{~nm}$ dengan menggunakan spektrofotometer UV-Visibel dan dibuat kurva kalibrasi.

\section{Pembuatan Dekokta}

Potongan kecil kulit batang Luka Bahau sebanyak 6, 12, dan 18 gram diekstraksi dengan menggunakan metode dekok yaitu dengan menggunakan aquadest dalam panci dekok bertingkat pada suhu $90^{\circ} \mathrm{C}$ selama 30 menit. Hasil dari ekstraksi tersebut diperoleh residu dan larutan dekok kulit batang Luka Bahau.

\section{Pemberian Dekokta Luka Bahau}

Pemberian dekokta Luka Bahau dilakukan secara oral (intubasi oesophagus) tiga kali sehari yaitu pagi, siang dan sore satu jam setelah pemaparan bahan uji asap rokok selama 7 hari dengan konsentrasi 2,3\%;3,13\% dan 4,1\% /kg BB.

\section{Pengujian Aktivitas Antioksidan}

\section{Perlakuan Hewan Percobaan.}

Hewan yang digunakan dalam penelitian ini adalah tikus putih jantan (Rattus norvegicus) galur wistar. Sampel diperoleh secara acak yaitu tikus putih jantan galur wistar, berat badan \pm 200 gram. Seluruh hewan percobaan diadaptasikan selama tujuh hari. Tikus yang diadaptasi akan diberikan makan dan minum secukupnya. Hewan percobaan dibagi menjadi lima kelompok perlakuan. Kelompok A merupakan kelompok normal tanpa paparan asap rokok dan perlakuan. 
Kelompok B adalah kelompok kontrol negatif yang hanya diberikan paparan asap rokok dan air suling. Kelompok C, D dan E adalah kelompok perlakuan yang diberikan paparan asap rokok dan dekok kulit batang $C$. verum dengan konsentrasi yang berbeda. Rokok yang digunakan adalah rokok filter. Proses pemaparan dilakukan setiap pagi, siang dan sore menggunakan 1 batang rokok setiap 1 kali pemaparan. Pemaparan dilakukan selama 7 hari didalam sebuah wadah yang terbuat dari kaca berukuran $38,5 \times 28,5 \times 22,5 \mathrm{~cm}$ yang dilengkapi dengan ventilasi, satu buah pompa udara dan tempat pembakaran rokok.

\section{Pengambilan Sampel Darah}

Dimasukkan hewan coba ke dalam holder untuk mempermudah proses pengambilan darah melalui ekor, Diusap bagian ekor tikus dengan kapas yang telah dibasahi dengan etanol $70 \%$, lalu dipotong sedikit ujung ekor tikus. Diusap secara perlahan dari pangkal hingga ujung ekor, ditampung $1 \mathrm{~mL}$ darah yang keluar dan dikumpulkan dalam microtube. Disentrifugasi darah yang telah ditampung dalam tabung reaksi pada tahap sebelumnya dengan kecepatan 3000 rpm selama 15 menit. Diambil supernatan untuk pengujian tahap selanjutnya. Pengambilan darah hewan coba diambil sebelum dan setelah pemaparan.

\section{Pengukuran Kadar MDA Sampel}

Dipipet $1 \mathrm{~mL}$ supernatan (serum) dari semua kelompok, baik kelompok uji maupun kontrol ke dalam tabung reaksi. Ditambahkan TCA 20\% sebanyak $1 \mathrm{~mL}$. Disentrifugasi dengan kecepatan $3000 \mathrm{rpm}$ selama 10 menit. Dipipet $1 \mathrm{~mL}$ supernatan dan ditambahkan dengan $1 \mathrm{~mL}$ TBA $0,01 \%$. Diukur absorbansi dari warna yang terbentuk pada $\chi=531 \mathrm{~nm}$ dengan menggunakan spektrofotometer UV-Visibel. Dihitung kadar MDA sampel dengan menggunakan kurva kalibrasi dari TMP.

\section{HASIL DAN PEMBAHASAN}

Sumber radikal bebas yang digunakan adalah asap rokok yang berasal dari rokok filter. Hewan uji tikus dikondisikan sebagai perokok pasif yang terpapar asap rokok. Asap yang dilepaskan ke udara lebih berbahaya karena kandungan nikotin yang lebih tinggi (4-6 kali) dibandingkan asap rokok yang dihisap oleh perokok ${ }^{4}$. Hewan uji diberi paparan asap rokok selama 7 hari dengan satu batang rokok pada setiap kali pemaparan selama tiga kali sehari.Digunakan 1 batang, dikarenakan ini adalah jumlah terkecil seorang perokok untuk merokok setiap harinya. Pemaparan rokok merupakan metode yang relatif mudah dan sensitif untuk menyelidiki efek spesifik dari asap rokok pada stress oksidatif. Paparan asap rokok dapat menyebabkan kerusakan jaringan yang diikuti dengan peningkatan produk peroksidasi lipid.

Sebelum diberikan perlakuan semua hewan uji diadaptasikan selama satu minggu untuk menghindari resiko timbulnya stres selama proses transportasi serta menyeragamkan pola makan ataupun pola hidup dengan lingkungan baru. Perlakuan ini bertujuan untuk meningkatkan berat badan tikus hingga sesuai dengan berat badan yang diinginkan pada pengujian. Berat badan yang digunakan pada saat pengujian berkisar antara 100-200 gram. Hal ini menandakan hewan uji berada dalam kondisi lingkungan yangsama sehingga diharapkan tidak menimbulkan hasil yang bias pada pengukuran kadar MDA.

Metode pengukuran MDA yang digunakan adalah metode TBA (Thiobarbituric Acid). Menurut Yagi 1994, metode TBA mempunyai nilai kepekaan yang tinggi terhadap radikal bebas dan mudah diaplikasikan untuk sampel dalam berbagai tahap oksidasi. TBA akan bereaksi dengan gugus karboksilat dari MDA melalui penambahan nukleofilik membentuk kompleks MDA-TBA dan menghasilkan produk yang berwarna sehingga dapat dikuantifikasi dengan spektrofotometri.

Persamaan kurva baku diperoleh setelah membuat kurva baku kalibrasi TMP dengan menggunakan larutan standar yaitu 1,1,3,3-tetrametoksipropana. TMP merupakan prekusor 
dari MDA karena sifatnya yang tidak stabil sehingga dijadikan sebagai standar MDA. TMP akan dihidrolisis oleh air menjadi MDA dan alkohol. Panjang gelombang MDA yang diperoleh dari pembuatan kurva baku adalah $531 \mathrm{~nm}$. Persamaan kurva baku yang diperoleh adalah $\mathrm{y}=0,115 \mathrm{x}+0,068$ dengan $\mathrm{r}=0,997$. Kurva regresi linier MDA dapat dilihat pada Gambar 1.

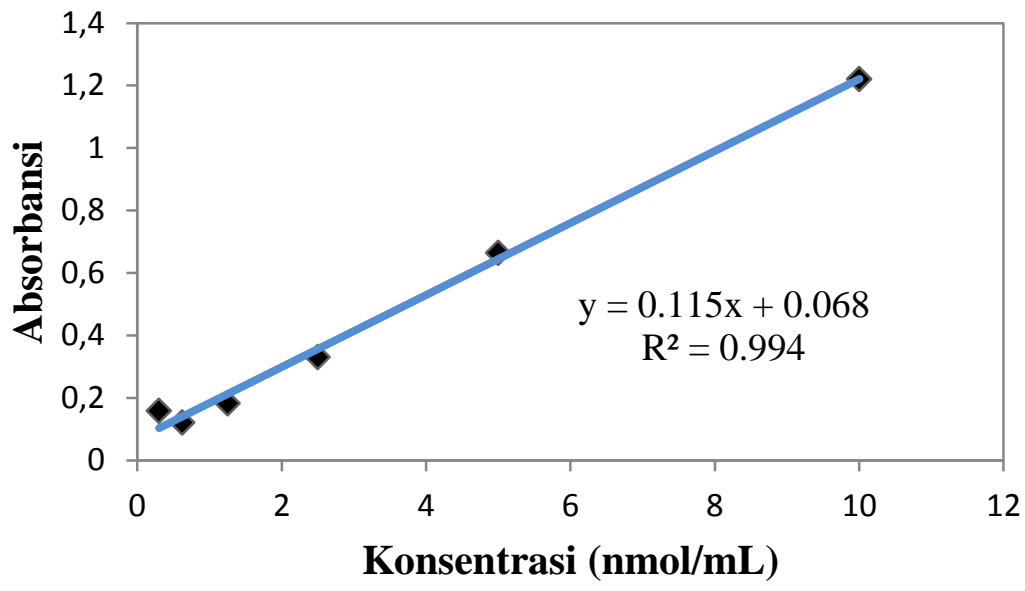

Gambar 1. Kurva Regresi Linier MDA

Analisis kadar MDA dilakukan dengan menggunakan serum darah tikus yang diukur menggunakan spektrofotometer. Pengukuran MDA pada serum darah karena sebagian besar MDA pada darah terdapat di dalam serum, selain pada plasma dan jaringan, digunakan serum juga bertujuan untuk menghindari tercemarnya specimen oleh koagulasi sehingga serum darah yang diperoleh selanjutnya digunakan untuk pemeriksaan kadar MDA. Serum yang diperoleh kemudian ditambahkan TCA 20\% dan TBA 0,0 1\%. Penambahan TBA dilakukan agar dapat bereaksi sempurna dengan MDA, sedangkan TCA berfungsi untuk mengendapkan protein yang terdapat di dalam serum. Selanjutnya dilakukan inkubasi selama 45 menit pada suhu $100^{\circ} \mathrm{C}$ untuk mempercepat reaksi.

Tabel 1. Rerata Perubahan Kadar MDA,

\begin{tabular}{cccc} 
No & \multirow{2}{*}{$\begin{array}{c}\text { Kelompok } \\
\text { Perlakuan }\end{array}$} & \multicolumn{2}{c}{ Rerata Kadar MDA $(\mathbf{n m o l} / \mathbf{m L})$} \\
\cline { 3 - 4 } & Kontrol Normal & 0,385 & Hari Ke-7 \\
\hline $\mathbf{1}$ & Kontrol Negatif & 0,432 & 0,333 \\
$\mathbf{2}$ & Kontrasi 2,3 \% & 0,475 & 0,504 \\
$\mathbf{3}$ & Konsentrasi & 0,634 \\
$\mathbf{4}$ & Konsentrasi 3,13\% & 0,507 & 0,333 \\
$\mathbf{5}$ & Konsentrasi 4,1 \% & 0,53 & 0,148 \\
\hline
\end{tabular}

Berdasarkan table diatas terlihat bahwa pada kelompok normal telah terbentuk MDA di dalam tubuh, namun masih dalam kadar yang relatif konstan atau tetap. Dalam keadaan normal tubuh akan tetap memproduksi radikal bebas dalam jumlah tertentu sebagai hasil samping dari reaksi pernafasan, metabolisme dan berbagai mekanisme endogen tubuh lainnya. Senyawa radikal tersebut diproduksi di dalam sel oleh mitokondria, membran 
plasma, lisosom, peroksisom, reticulum endoplasma dan inti sel. Keberadaan radikal-radikal ini tetap akan bereaksi dengan lipid membran tubuh, karena lipid merupakan komponen utama penyusun sel yang kaya akan ikatan rangkap, sehingga lipid merupakan target utama senyawa radikal bebas, namun masih dapat dinetralisir oleh antioksidan endogen tubuh. Sehingga kadar MDA tetap terbentuk, namun masih di dalam rentang yang wajar. Peningkatan kadar MDA tetap terjadi secara signifikan pada kelompok kontrol negatif yaitu kelompok yang dipaparkan asap rokok dan aquades. Hal ini memperlihatkan bahwa asap rokok mampu meningkatkan jumlah radikal bebas dalam tubuh.

Radikal bebas dari asap rokok menyebabkan terjadinya peroksidasi asam lemak tak jenuh membran sel yang memperkuat stres oksidatif, sehingga akanterjadi peningkatan kadar MDA akibat adanya paparan asap rokok. Rokok dapat meningkatkan kadar MDA secara signifikan pada perokok pasif dan perokok aktif baik terhadap hewan uji tikus maupun manusia ${ }^{2}$. Meningkatnya konsentrasi lipid peroksida yang terukur menggambarkan gagalnya mekanisme pertahanan antioksidan endogen dalam kehadiran radikal bebas yang berlebih $^{6}$.Pada penelitian ini untuk mencegah kondisi stress oksidatif tersebut digunakan dekoktakulit batang luka bahau (Cinnamomum verum)dengan konsentrasi 2,3\%;3,13\%; 4,1\%/kg BB yang diberikan setelah satu jam pemaparan selama tujuh hari.

Stres oksidatif yang ditandai dengan meningkatnya kadar peroksidasi lemak yaitu kadar MDA akibat paparan asap rokok dapat diturunkan dengan pemberian dekokta Cinnamomum verum. Hal itu terbukti pada penelitian ini dimana kadar MDA pada semua kelompok yang dipapar asap rokok dan mendapat dekokta Cinnamomum verumlebih rendah dibanding kelompok yang hanya dipapar asap rokok. Penurunan yang paling bermakna adalah terjadi pada kelompok konsentrasi yang mendapat dekokta Cinnamomum verumpada konsentrasi 3,13\% dan 4,1\% dapat menekan terjadinya peroksidasi lipid yang ditunjukkan dengan penurunan kadar MDA secara berturut-turut sebesar $17,4 \%$ dan $38 \%$ pada tikus yang terpapar asap rokok dibandingkan dengan kelompok dekokta 2,3\% dan kontrol negatif. Dari uraian hasil penelitian di atas, hipotesa bahwa dekokta Cinnamomum verummampu memberikan proteksi terhadap stres oksidatif tikus akibat paparan asap rokok terbukti. Kemampuan dalam menurunkan kadar MDA karena diduga kandungan flavonoid dan fenolik dari dekokta Cinnamomum verum.

Komponen fenolik merupakan terminator dari radikal bebas dan sebagai pengkelat ion logam redoks aktif. Ion logam ini memungkinkan peranannya untuk mengatalisis reaksi peroksidasi lipid ${ }^{7}$. Antioksidan fenolik ini menghalangi oksidasi lipid dan molekul lain dengan cara mendonasikan atom hidrogen ke senyawa radikal membentuk intermediet radikal fenoksil ${ }^{3}$. Senyawa intermediet radikal fenoksil relatif stabil sehingga tidak mampu lagi menginisiasi reaksi radikal selanjutnya. Aktivitas biologis yang tinggi pada senyawa fenolik ini terletak pada posisi dan jumlah gugus $-\mathrm{OH}^{8}$.Belum diketahui jenis senyawa flavonoid dan fenolik dalam penelitian ini yang berperan dalam menurunkan kadar MDA.

Dengan demikian, penggunaan dekokta Cinnamomum verumsebagai obat secara tradisional dalam dosis tertentu dapat dibenarkan secara ilmiah meskipun masih diperlukan penelitian lebih lanjut mengenai penggunaannya pada manusia. Penelitian lanjutan yang dapat dilakukan adalah tentang dosis efektif, toksisitas dan efek sampingnya pada manusia.

\section{KESIMPULAN}

Kulit batang Luka Bahau dapat mempengaruhi kadar MDA tikus putih yang diberi paparan asap rokok. Konsentrasi efektif dekokta Luka Bahau (Cinnamomum verum) adalah konsentrasi $3,13 \% / \mathrm{kg}$ BB yang dapat mempengaruhi kadar MDA tikus yang terpapar asap rokok. 


\section{DAFTAR PUSTAKA}

Fitria, R.I.N.K Retno Triandhini, Jubhar C. Mangimbulude, Ferry F.Karwur., 2013 Merokok dan Oksidasi DNA., Sains Medika Vol.5, No.2.

Tyndale, R.F \& Sellers, E. 2005.,Variable CYP2a6 Mediated Nicotine Metabolism Alters Smoking Behavior and Risk. The American Society or Pharmacology and Experimental Therapeutics. Vol. 29 No.4.

Hukkanen, J.,Jacob P dan Benowitz,N.L.,2005., Metabolism and Disposition Kinetics of Nicotine. The american Society for Pharmacology and Experimental Therapeutics. Vol.57,No.1.

Tjakradidjaja and Tjakradidjaja. 2011. Pomegranate (Punica granatum L) powder reduced malondialdehyde (MDA) level in cigarette smoke exposed rats. Med J Indones 2011; 20:34-9.

McPhee, M.A,, Papadakis, \& L.M. Tierney Jr (Eds). 2007. Current Medical Diagnosis and Treatment, 47th Edition,New York., McGraw-Hill.

Amic, D., Beslo, D., Trinajstic, N.,\&Davidovic. 2002. Structure-Radical Scavenging Activity Relationships of Flavonoids. Croatia Chemica Acta, 6(1), 55-61.

Zaramba, M.N. 2008. Relationships 17. Among Antioxidants, Phenolics, and Specific Gravity in Potato Cultivars, and Evaluation of Wild Potato Species for Antioxidants, Glycoalkaloids, and Anti-Cancer Activity on Human Prostate and Colon Cancer CellsIn Vitro. Disertasi. Texas A\&M University. Vol. 1 No. 2.

Wayan, S., \&I Made, J. 2012. Ekstrak Air Daun Ubi Jalar Ungu Memperbaiki Profil Lipid dan Meningkatkan Kadar SOD Darah Tikus yang Diberi Makanan Tinggi Kolesterol. Medicina, 43(2), 67-70. 